\title{
The Relationship between the Use of Macromedia Flash-Based Learning Media and the Retention of Class IV Elementary School Students
}

\author{
Ida Ermiana \\ Primary School Teacher Education \\ Study Program \\ University of Mataram \\ Mataram, Indonesia
}

\author{
Lalu Hamdian Affandi \\ Primary School Teacher Education \\ Study Program \\ University of Mataram \\ Mataram, Indonesia
}

\author{
Awal Nur Kholifatur Rosyidah \\ Primary School Teacher Education \\ Study Program \\ University of Mataram \\ Mataram, Indonesia
}

\author{
Muhammad Erfan \\ Primary School Teacher Education Study Program \\ University of Mataram \\ Mataram, Indonesia
}

\author{
Vivi Rachmatul Hidayati* \\ Primary School Teacher Education Study Program \\ University of Mataram \\ Mataram, Indonesia \\ vivirachma@unram.ac.id
}

\begin{abstract}
This study aims to determine the effectiveness of learning assisted by Macromedia flash media in fourthgrade elementary school students and to determine the relationship between the use of Macromedia flash media and the retention of fourth-grade elementary school students. This research is a quantitative study and was conducted using a quasi-experimental method. The population in this study was 120 students. The sample of this study was 25 students using simple random sampling. Data were collected by using multiple-choice test techniques and conducted 3 (three) times, namely pretest, posttest, and retention test. The results showed that there was an effect of using Macromedia flashbased learning media on student learning outcomes and there was a correlation between the use of Macromedia flash-based learning media on class student retention. The relationship obtained is a negative relationship, which means that the higher the gain value (use of learning media), the lower the student's retention.
\end{abstract}

Keywords - Learning Media, Macromedia Flash, Retention

\section{INTRODUCTION}

Retention is an interesting topic when it comes to education and psychology. In general, retention is closely related to memory or memory. Students absorb a lot of knowledge in various fields within a specified time [1]. Forgetting becomes inevitable for students. The teacher focuses on his efforts to assist so that students get new concepts, materials, and knowledge, even so, new things students get can be forgotten [2]. Forgetting or not surviving a new knowledge in students' memory is due to several things. One of them is the distance between the acquisition of new information and the test time given by the teacher and the absence of the teacher's effort to review the material during that time [3]. Material review can be realized in various forms of activity. One of them is training activities. Structured exercises can help students to remember so that student retention is better [4]. Exercises can also take the form of periodic exams according to the material presented. The teacher will usually give a structured test for each learning topic to strengthen students' knowledge about that topic [2].

Strengthening retention can also be pursued through the use of media during learning. Learning media is an important component in learning [5]. Learning media provide opportunities for students to be more active so that learning is not centered on the teacher. Learning media that are currently being developed are computer-assisted. This is because nowadays students find it easier to get information through gadgets (Astra, Nasbey, \& Nugraha, 2015; Westera, 2012). The use of computer-based media in learning has several hopes, including being able to help students gain knowledge optimally and ease the task of teachers in providing facilities in learning. The use of instructional media can attract students' interest in learning and increase the absorption of knowledge in the topic or material presented [8]. Good absorption of material will help students have a good memory of the newly acquired knowledge. This shows that the use of instructional media has a good effect on student retention.

The influence of learning media on student retention has been studied by [9] which shows that computer-based learning media can improve students' memory. Computerbased media can improve students' memory in several learning topics, especially on topics that contain many basic concepts [10]. Computer-assisted learning can improve student memory and help teachers to provide learning facilities that are more attractive to students [11]. There is software that can be used to improve student learning outcomes and memory. research conducted by [12] shows that the use of learning software can show a positive effect on learning outcomes and memory of elementary students. Macromedia flashes as a multimedia and animation software that can be used to create interactive animations on web pages create presentations, games, and other creations that can combine graphics, sound animation, also have interactivity capabilities with users. The attractiveness of media in Macromedia flash can increase student learning motivation and students can learn interactively [13]. 
Based on the explanation above, the researcher examined the relationship between the use of these media and student retention. The computer-aided media referred to in this study is a Macromedia flash-based learning media that has previously been developed and tested for validity.

\section{Methods}

This research is quantitative research with computational techniques and correlational approaches. The comparative technique was used to test the effectiveness of using Macromedia Flash-based learning media in Theme 6 on the learning outcomes of fourth-grade students of SD Negeri 15 Cakranegara. The correlational approach is used to determine the relationship between the effectiveness of using Macromedia Flash-based learning media with the retention ability of students.

The population in this study were 120 elementary school class IV students in cluster 2 of the Cakranegara sub-district which consisted of 4 schools, namely SDN 15 Cakranegara, SDN 11 Cakranegara, SDN 24 Cakranegara, and SDN 36 Cakranegara. The sample taken from the population in this study amounted to 28 students from class IVA and IVB SD Negeri 15 Cakranegara. The data collection instrument used in this study was a multiple-choice test that was given three times, namely during the pre-test, post-test, and retention tests.

Data analysis on the computational technique was carried out by comparing the significance of the pre-test mean values and the post-test mean values by first doing the prerequisite analysis test (normality and homogeneity tests of the data). Tests carried out at the data analysis stage using computational techniques were carried out with paired sample t-tests, and data analysis on the correlational approach was carried out by using the Pearson Product Moment correlation test.

\section{RESULTS AND DISCUSSION}

Before testing the hypothesis regarding the effectiveness and relationship between the effectiveness of using Macromedia Flash learning media with the retention ability of students, a prerequisite analysis test was conducted on the pre-test and post-test results of students in the form of a normality test and a homogeneity test. The results of the normality test are presented in Table I.

TABLE I. RESUlTS OF NORMALITY TEST FOR ClASS 4A AND Class 4B

\begin{tabular}{llccc}
\hline No. & Data & df & Sig. & Conclusion \\
\hline 1. & Pre-Test 4A & 11 & 0.430 & Data is normally distributed \\
2. & Pre-Test 4B & 11 & 0.064 & Data is normally distributed \\
3. & Post-Test 4A & 11 & 0.985 & Data is normally distributed \\
4. & Post-Test 4B & 11 & 0.079 & Data is normally distributed \\
\hline
\end{tabular}

The normality test is carried out using a confidence level of $95 \%$ or equivalent to $\alpha$ of 0.05 . Table I shows that all the data collected, both pre-test class 4A, class 4B pre-test, class 4A post-test, and class 4B post-test, are normally distributed with a greater Significance (Sig.) Value. Than 0.05.

The homogeneity test is carried out to see whether the two classes tested have the same variant or variance or not.
The homogeneity test is one of the prerequisites for data analysis for the paired sample t-test. The results of the homogeneity test as one of the prerequisite tests are presented in Table II.

TABLE II. TABle 2. Result of Homogeneity TeSt of PRE-Test AND POST-TEST VALUES

\begin{tabular}{lllllc}
\hline No. & \multicolumn{1}{c}{ Data } & df1 & df2 & Sig. & Conclusion \\
\hline 1. & Pre-test (4A \& 4B) & 1 & 23 & 0.570 & homogeneous \\
2. & Post-test (4A \& 4B) & 1 & 23 & 0.107 & homogeneous \\
\hline
\end{tabular}

Based on the results of the homogeneity test presented in Table II, it is known that the significance value (Sig.) Of each data is 0.570 and 0.107 , both of which are greater than $\alpha(0.05)$, so it can be concluded that the pre-test and posttest data both have the same or homogeneous data variants.

The data in this study have met the analysis prerequisite test, namely normal and homogeneous so that further hypothesis testing can be carried out with a paired sample ttest to test the effectiveness of using Macromedia Flashbased learning media on student learning outcomes, and Pearson Product Moment correlation test to determine the relationship between effectiveness. the use of Macromedia Flash-based learning media with the ability to retain students. Paired samples t-test results are presented in Table III.

TABLE III. PAIRED SAMPLE T-Test Results PRE-TEST AND POSTTEST VALUES

\begin{tabular}{llllll}
\hline \multicolumn{1}{c}{ Data } & t & df & Sig. & $\begin{array}{c}\text { Hypothesis } \\
\text { testing }\end{array}$ & Conclusion \\
\hline $\begin{array}{l}\text { Pre-test vs } \\
\text { Post-test }\end{array}$ & - & 24 & 0.000 & Ho rejected & $\begin{array}{l}\text { There is a } \\
\text { difference in } \\
\text { average }\end{array}$ \\
\hline
\end{tabular}

Table III shows the significance value (Sig.) is much smaller than the $\alpha$ value. This means that Ho, which reads "there is no significant average difference between the pretest and post-test scores" is rejected, and there is a significant difference in mean between the pre-test and posttest scores of students after being given the treatment. in the form of learning with Macromedia Flash.

TABLE IV. PEARSON CORRELATION TEST RESUlTS

\begin{tabular}{llccl}
\hline \multicolumn{1}{c}{ Data } & $\begin{array}{c}\text { Pearson } \\
\text { Correlation }\end{array}$ & Sig. & $\begin{array}{c}\text { Hypothesis } \\
\text { testing }\end{array}$ & Conclusion \\
\hline $\begin{array}{l}\text { gain value }- \\
\text { retention } \\
\text { value }\end{array}$ & -0.518 & 0.008 & Ho rejected & $\begin{array}{l}\text { There is a } \\
\text { correlation }\end{array}$ \\
\hline
\end{tabular}

Based on Table IV, it is known that the significance value (Sig.) Obtained is 0.008 which is smaller than $\alpha$. Ho, which reads "there is no significant relationship between the gain value and the retention value" is rejected. This means that there is a relationship between the gain value and the student retention value. In this case, it can be concluded that there is a significant relationship between the use of Macromedia Flash-based learning media with student retention scores. It is known that the correlation between the gain value and the retention value is negative $(-0.518)$. This indicates that the greater or greater the independent variable 
(gain value), the lower the dependent variable (retention value).

The normality and homogeneity tests were carried out previously as a prerequisite test. The normality test shows that the data is normally distributed and the homogeneity test has the same variant or homogeneity. Hypothesis test results state that there is a significant average difference between students' pretest scores and their post-test scores. The use of learning media based on Macromedia flash affects learning outcomes (in this case the student competency test scores). The pre-test is carried out by students before getting treatment in the form of using Macromedia flash-based learning media. The mean pre-test scores were 42.5 for class $4 \mathrm{~A}$ and 46.15 for class $4 \mathrm{~B}$. This value is classified as low and is below the minimum standard. After being given treatment in the form of mediaassisted learning, students were given post-test questions. The students' post-test mean scores were 61.79 for class $4 \mathrm{~A}$ and 73.85 for class 4B. It was clear that there was an increase in the value before and after being given treatment.

From the results of the Pearson correlation test, it was found that there was indeed a relationship between media use and students' memory. The material packaged in Macromedia flash software makes it easy for students to remember, besides that students are more interested in learning, more motivated to take part in learning, can read through a text, watch animation through videos in the media. With students learning fun, being motivated in learning will also give better results. This indirectly makes students' memories of the material that has been studied easier to remember, so that when given a test student learning outcome even though with a time interval of a few days it is still good. These results are further supported by research conducted by Umam \& Yudi (2016) which states that there is a positive influence on the use of Macromedia Flash media on student mathematics learning outcomes. In line with the results of research conducted by Ermiana et al. (2020) showed that learning media based on Macromedia flash influenced students 'conceptual understanding when treatment with Macromedia flash students' concept understanding was higher than not using Macromedia flash in learning. Nalurita et al. (2010) also added that the use of media in learning is very necessary to make it easier for students to understand the material presented by the teacher.

Currently, the digital era requires teachers to be able to develop computer-based media, one of which is Macromedia Flash. Bernard (2014) also obtained research results in the form of a significant influence on student learning outcomes using Macromedia Flash-based media in learning. Macromedia Flash-based learning media has a positive influence on student learning motivation [13]. In addition, Marpaung \& Siagian (2016) also stated that the use of interactive learning media (in this case Macromedia Flash-based media) can improve the learning outcomes of elementary school students.

The variable of media use becomes data with the type of scale, so the gain value is sought first. This gain value will later become a variable that uses media. The results show that there is a relationship between the gain value and retention. This means that there is a relationship between media use and student retention. Based on the test using SPSS, it was concluded that the higher the gain value, the lower the student retention. Research that focuses specifically on looking for the relationship between media use and student retention is not yet specific. Even so, based on the results of the Pearson correlation test, it was found that there was indeed a relationship between media use and students' memory. This is related to the research by Gowasa et al. (2019) which shows that there is a significant difference in the memory of students who are given treatment in the form of learning media and those that are not. Not only that, but Permatasari et al. (2017) also obtained the results of the study that there was a difference in the retention of students who were taught using media and those who were not. This is also supported by the results of research from Ramdhani (2015) that there is an increase in the retention (memory) of students with disabilities when given treatment in the form of media-assisted learning.

\section{CONCLUSION}

Based on the results of the research and discussion, it can be concluded that there is an effect of using Macromedia Flash-based learning media on the learning outcomes of fourth-grade students of SDN 15 Cakranegara, besides that there is also a relationship (correlation) between the use of Macromedia flash-based learning media on the retention of fourth-grade students of SDN 15 Cakranegara. The relationship obtained is a negative relationship, which means that the higher the gain value (use of learning media), the lower the student's retention.

\section{ACKNOWLEDGMENT}

The research team would like to thank the University of Mataram for funding the research, namely through the PNBP funding source for the 2020 Fiscal Year.

\section{REFERENCES}

[1] J. Dunlosky dan K. A. Rawson, "Overconfidence produces underachievement: Inaccurate self-evaluations undermine students' learning and retention," Learn. Instr., vol. 22, no. 4, hal. 271-280, Agu 2012, doi: 10.1016/j.learninstruc.2011.08.003

[2] R. V. Lindsey, J. D. Shroyer, H. Pashler, dan M. C. Mozer, “Improving Students' Long-Term Knowledge Retention Through Personalized Review," Psychol. Sci., vol. 25, no. 3, hal. 639-647, Mar 2014, doi: 10.1177/0956797613504302.

[3] P. K. Agarwal, J. R. Finley, N. S. Rose, dan H. L. Roediger, "Benefits from retrieval practice are greater for students with lower working memory capacity," Memory, vol. 25, no. 6, hal. 764-771, Jul 2017, doi: 10.1080/09658211.2016.1220579.

[4] L. Rinne, E. Gregory, J. Yarmolinskaya, dan M. Hardiman, "Why Arts Integration Improves Long-Term Retention of Content," Mind, Brain, Educ., vol. 5, no. 2, hal. 89-96, Jun 2011, doi: 10.1111/j.1751-228X.2011.01114.x.

[5] S. Nelwati, N. Sepriyanti, A. Susanto, M. Melinda, dan J. Afriadi, "The development of islamic learning media using macromedia flash on geometry," J. Phys. Conf. Ser., vol. 1317, hal. 012125, Okt 2019, doi: 10.1088/17426596/1317/1/012125

[6] I. M. Astra, H. Nasbey, dan A. Nugraha, "Development Of An Android Application In The Form Of A Simulation Lab As Learning Media for Senior High School Students," EURASIA J. Math. Sci. Technol. Educ., vol. 11, no. 5, Agu 2015, doi: 10.12973/eurasia.2015.1376a.

[7] W. Westera, "The eventful genesis of educational media," Educ. Inf. Technol., vol. 17, no. 3, hal. 345-360, Sep 2012, doi: 
10.1007/s10639-011-9162-z.

[8] N. Hidayati dan A. I. Wuryandari, "Media Design for Learning Indonesian in Junior High School Level," Procedia - Soc. Behav. Sci., vol. 67, hal. 490-499, Des 2012, doi: 10.1016/j.sbspro.2012.11.354.

[9] M. Granito dan E. Chernobilsky, "The Effect of Technology on a Student's Motivation and Knowledge Retention," in NERA Conference Proceedings, 2012, hal. 17.

[10] S. Rondon, F. C. Sassi, dan C. R. Furquim de Andrade, "Computer game-based and traditional learning method: a comparison regarding students' knowledge retention," BMC Med. Educ., vol. 13, no. 1, hal. 30, Des 2013, doi: 10.1186/14726920-13-30.

[11] J. L. Fernández Alemán, J. M. Carrillo de Gea, dan J. J. Rodríguez Mondéjar, "Effects of competitive computer-assisted learning versus conventional teaching methods on the acquisition and retention of knowledge in medical surgical nursing students," Nurse Educ. Today, vol. 31, no. 8, hal. 866871, Nov 2011, doi: 10.1016/j.nedt.2010.12.026.

[12] O. Pilli dan M. Aksu, "The effects of computer-assisted instruction on the achievement, attitudes and retention of fourth grade mathematics students in North Cyprus," Comput. Educ., vol. 62, hal. 62-71, Mar 2013, doi: 10.1016/j.compedu.2012.10.010.

[13] L. N. Zulfa, I. Ermiana, dan L. H. Affandi, "Pengaruh Media Pembelajaran Berbasis Macromedia Flash Terhadap Motivasi Belajar Siswa Kelas IV B SDN 1 Rumak Kecamatan Kediri Tahun Pelajaran 2018/2019," Indones. J. Elem. Child. Educ., vol. 1, no. 2, hal. 44-50, 2020.

[14] K. Umam dan Y. Yudi, "Pengaruh Menggunakan Software Macromedia Flash 8 Terhadap Hasil Belajar Matematika Siswa Kelas VIII.," Kalamatika J. Pendidik. Mat., vol. 1, no. 1, hal. 84-92, 2016.

[15] I. Ermiana, I. N. Karma, dan L. H. Affandi, "The Effectiveness of Multimedia-Based Learning on Students' Concept Understanding at Grade 4 Elementary School in Kediri District," in Proceedings of the 1st Annual Conference on Education and Social Sciences (ACCESS 2019), 2020, hal. 238241, doi: 10.2991/assehr.k.200827.060.

[16] L. Nalurita, R. A. Siroj, dan R. Ilma, "Bahan Ajar Kesebangunan dan Simetri Berbasis Contextual Teaching and Learning (CTL) Menggunakan Macromedia Flash di Kelas 5 Sekolah Dasar," J. Pendidik. Mat., vol. 4, no. 1, hal. 45-52, 2010.

[17] M. Bernard, "Pengaruh pembelajaran dengan menggunakan multimedia macromedia falsh terhadap kemampuan penalaran matematik," in Prosiding Seminar Nasional Pendidikan Matematika Program Pascasarjana STKIP Siliwangi Bandung, 2014, hal. 425-429.

[18] I. Y. O. Marpaung dan S. Siagian, "PENGEMBANGAN MEDIA PEMBELAJARAN BAHASA INDONESIA BERBASIS MACROMEDIA FLASH PROFFESIONAL 8 KELAS V SD SWASTA NAMIRA," J. Teknol. Inf. Komun. DALAM Pendidik., vol. 3, no. 1, Jun 2016, doi: 10.24114/jtikp.v3i1.5003.

[19] S. Gowasa, F. Harahap, dan R. D. Suyanti, "Perbedaan Penggunaan Media Powerpoint dan Video Pembelajaran Terhadap Kemampuan Berpikir Tingkat Tinggi dan Retensi Memori Siswa pada Mata Pelajaran IPA di Kelas V SD," $J$. Temat., vol. 9, no. 1, hal. 19-27, 2019, doi: 10.24114/jt.v9i1.12859.

[20] T. P. Permatasari, D. Hadiarti, dan R. Fadhilah, "EFEKTIVITAS MEDIA MIND MAP BERBASIS METODE LATIHAN BERJENJANG TERHADAP HASIL DAN RETENSI BELAJAR SISWA PADA MATERI KONSEP MOL DI KELAS X SMA NEGERI 8 PONTIANAK," AR-RAZI J. Ilm., vol. 5, no. 2, Okt 2017, doi: 10.29406/arz.v5i2.639.

[21] I. M. Ramdhani, "PENGEMBANGAN MEDIA FLASH CARD SISTEM PERIODIK UNSUR UNTUK MENINGKATKAN RETENSI DAYA INGAT PESERTA DIDIK DISABILITAS PENDENGARAN DI SMA," INKLUSI, vol. 2, no. 2, hal. 243, Des 2015, doi: 10.14421/ijds.2204. 